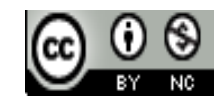

Jurnal Bimbingan Konseling Indonesia is licensed under

A Creative Commons Attribution-Non Commercial 4.0 International License.

\title{
FAKTOR - FAKTOR YANG MENGHAMBAT SISWA DALAM MEMANFAATKAN LAYANAN INFORMASI KARIR DI SMP NEGERI 6 PALANGKA RAYA
}

\author{
Dony Apriatama ${ }^{1)}$ \\ 1) Prodi Bimbingan Konseling Islami Fakultas Ushuluddin Adab dan Dakwah IAIN Palangkaraya, Palangkaraya, Indonesia \\ E-mail: apriatamadony@gmail.com
}

\begin{abstract}
Abstrak. Layanan informasi merupakan salah satu dari beberapa kegiatan dalam rangka pelaksanaan program bimbingan di sekolah untuk membantu siswa mengenal lingkungannya yang di manfaatkan baik saat ini maupun dimasa yang akan datang. Tujuan Penelitian ini yaitu ingin mengetahui faktor-faktor yang menghambat siswa dalam memanfaatkan layanan informasi karier di SMP Negeri 6 Palangka Raya. Penelitian ini menggunakan metode deskriptif yaitu, suatu metode penelitian yang memusatkan pemecahan masalah-masalah yang digunakan untuk membuat gambaran tentang suatu keadaan secara objektif pada situasi sekarang. Berdasarkan hasil penelitian tersebut maka dapat diketahui bahwa secara umum faktor-faktor penghambat siswa kelas VIII dalam memanfaatkan layanan informasi karier di SMP Negeri 6 Palangka Raya tahun ajaran 2016/2017 berada pada tingkat kategori cukup dominan dengan persentase rata-rata 70,45\%. Peneliti menyarankan Hendaknya digunakan sebagai bahan acuan dan pertimbangan dalam penyusunan program pendidikan selanjutnya untuk membantu faktor penghambat siswa dalam memanfaatkan layanan informasi karier. Dapat sebagai masukan untuk mendukung guru bimbingan konseling dalam meningkatkan pemahaman dan peran guru bimbingan dalam memberikan bimbingan yang berkaitan dengan faktor-faktor yang menghambat siswa dalam memanfaatkan layanan informasi karier. Hendaknya selalu bekerja sama dengan pihak sekolah untuk mengatasi penyebab faktor-faktor yang menghambat siswa dalam memanfaatkan layanan informasi karier.
\end{abstract}

Kata Kunci: Faktor-Faktor Yang Menghambat Siswa Dalam Memanfaatkan Layanan BK; Layanan Informasi Karir

\section{Pendahuluan}

Di era globalisasi yang ditandai dengan perubahan dan kemajuan yang sangat cepat menimbulkan berbagai tantangan, harapan dan persaingan bagi seluruh warga masyarakat. Setiap individu perlu menyiapkan diri untuk menghadapi setiap tantangan dengan berbagai pengetahuan dan keterampilan. Isi pokok yang terkandung dari pikiran tersebut, bahwa globalisasi merupakan sistem yang mempunyai dinamika dan karakteristik tersendiri. Pergeseran ketersedian informasi membuat manusia dibanjiri informasi yang penuh ketidakpastian, namun justru informasi ini menjadi sumber utama bagi manusia dan dari informasi itu sendiri bisa di gunakan untuk belajar dalam menyesuaikan diri agar dirinya tetap eksis adalah proses dan aktivitas yang terjadi dan melekat dalam kehidupan manusia sehari-hari karena ia selalu dihadapkan kepada lingkungan yang selalu berubah yang menuntut mereka harus selalu menyesuaikan, memperbaiki, mengubah dan meningkatkan mutu perilaku untuk dapat memungsikan diri secara efektif di dalam lingkungan.

Di lingkungan sekolah informasi itu dapat berlangsung secara terus menerus dan beragam, baik itu informasi tentang belajar, informasi antara orang tua dan guru dan sebagainya. Demikian juga dengan siswa yang baru mau memasuki jenjang sekolah yang lebih tinggi, akan memerlukan informasi tentang pendidikan atau sekolah yang mana yang cocok untuk diri siswa tersebut, baik itu letak sekolahnya, mutu sekolahnya, persyaratan untuk masuk ke sekolah tersebut, program pendidikannya, biaya sekolahnya, aktivitas dan klub sekolah, sarana dan prasarana, kurikulum yang ditawarkan, kemana mereka setelah tamat nanti dan lain-lain.

Semua itu adalah informasi yang diperlukan oleh siswa yang akan tamat dan melanjutkan pendidikannya ke jenjang yang lebih tinggi lagi, oleh karena itu, informasi yang akurat sangat membantu mereka untuk mempertimbangkan dalam 
mengambil keputusan karier yang tepat sesuai dengan potensi yang dimiliki siswa tersebut. Layanan informasi merupakan salah satu dari beberapa kegiatan dalam rangka pelaksanaan program bimbingan di sekolah untuk membantu siswa mengenal lingkungannya yang di manfaatkan baik saat ini maupun dimasa yang akan datang [1].

Suatu layanan informasi yang hidup harus memiliki sumber-sumber yang cukup memadai untuk mengumpulkan informasi dengan cepat, relevan dan muktahir serta dapat memperlancar pemberian informasi pada siswa agar mereka mampu memakai dan menggunakannya. Perolehan dan penggunaan informasi lingkungan memungkinkan untuk mengambil keputusan yang rasional, maka individu-individu yang memiliki informasi yang cukup memadai untuk akan mampu untuk memenuhi dan mengikuti tujuannya sesuai dengan intelegensia dan perasaannya.

Pendidikan semacam ini, memadukan persiapan hidup dan dunia kerja yang mencakup seluruh dominan belajar yang memadukan pendidikan umum dan kejuruan dalam sebuah kontinue pengetahuan, nilai, kompetensi, dan keterampilan. Dalam pandangan seperi ini, BK menempati peranan penting untuk membantu manusia mampu memenuhi kebutuhan belajar baru dan memberdayakan manusia untuk memperoleh manusia untuk memperoleh keseimbangan hidup, belajar dan bekerja. Hal-hal sebagaimana yang diungkapkan di atas berakibat langsung dan tidak langsung pada proses belajar mengajar disekolah apabila informasi tidak disampaikan dengan benar akhirnya sampai pada kenyataan yang menunjukkan bahwa sebagian tamatan sekolah menengah dipandang kurang bermutu.

Dalam konteks di atas, guru pembimbing memiliki peran dan tanggung jawab untuk memotivasi siswa agar mampu mengatasi masalah secara mandiri, serta mampu membelajarkan diri dengan baik, dengan kemampuan yang dimiliki guru tersebut untuk memberikan layanan bantuan. Layanan tersebut meliputi : layanan penilaian test dan nontest, layanan informasi, layanan konseling individual, layanan konseling kelompok, layanan perencanaan, penempatan dan tindak lanjut serta rujukan. Setelah melihat kenyataan masyarakat global saat ini yang tidak bisa lepaskan dari informasi, hal ini menandakan betapa pentingnya layanan informasi ini untuk dikembangkan lebih dalam pendidikan nasional yang di harapkan mampu mewujudkan tamatan yang berstandar dan kompeten.

Tidak disangsingkan lagi bahwa setiap orang yang hidup dalam pergaulan sosial masyarakat membutuhkan informasi. Begitupun disekolah, siswa memerlukan berbagai macam informasi atau penerangan informasi yang diperoleh siswa karena kadang-kadang ada informasi yang didapatnya keliru, kabur, kurang lengkap, dan kurang sistematis serta sering menyesatkan, sehingga membingungkan para siswa.

Dari hasil wawancara kepada 2 (dua) Guru BK di SMP Negeri 6 Palangkaraya, didapatkan informasi bahwa pada setiap pemberian informasi ada siswa yang menanggapi dengan antusias serta mencari informasi untuk mengatasi masalah tersebut, ada juga yang tidak menganggap penting layanan informasi yang diberikan kepada siswa atau mengabaikannya seperti tidak memperhatikan guru atau bolos pada saat pemberian informasi diberikan karena menganggap pemberian informasi itu tidak memiliki manfaat yang penting dalam pembelajaran, karena tidak berpengaruh langsung terhadap prestasi atau nilai kelulusan. Kebanyakan dari siswa tersebut banyak mengalami masalah-masalah seperti bingung menentukan pilihan karier yang sesuai dengan potensi bakat, minat, sikap dan kepribadiannya.

Masalah yang biasa dihadapi orang tua atau murid ialah masalah pemilihan sekolah lanjutan sehingga layanan informasi diperlukan sekali, baik itu jenis-jenis sekolah apa yang ada, apa wewenang setelah tamat sekolah tersebut, melanjutkan kemana setelah tamat, syarat apa yang harus dipenuhi untuk mengikuti pendidikan tersebut dan lain-lain. Fungsi layanan karier adalah mendorong siswa untuk dapat meniti karir dan merencanakan masa depannya. Disamping itu layanan bimbingan karir berfungsi untuk membantu dalam memahami diri dalam program pilihan sesuai dengan, minat, cita-cita dan kemampuan yang dimiliki.

Kemampuan siswa untuk membuat keputusan yang bijaksana sangat tergantung dari informasi yang tersedia, informasi harus valid dan harus dapat digunakan oleh siswa untuk membuat keputusan dalam hidup mereka. Sehingga setelah mendapatkan berbagai informasi itu siswa dapat membuat perencanaan untuk kegiatannya yang akan datang.

Tujuan layanan informasi karir akan tercapai apabila kegiatan bimbingan karir tersebut dapat berjalan dengan baik. Tujuan layanan informasi karir adalah untuk member pemahaman kepada siswa tentang karir yang dapat dipilih sesuai dengan kemampuan siswa itu sendiri. Seperti yang dikemukakan Popon Syarif dalam [2] tujuan layanan informasi karir adalah sebagai berikut: (1) Memahami karakteristik dirinya dalam hal minat, nilai-nilai, kecakapan, dan ciri-ciri kepribadian dan dapat mengidentifikasi bidang pekerjaan yang luas yang mungkin cocok. (2) Membedakan beberapa bidang kehidupan dalam hal kepuasan potensial, sifat hakekat kerja, kontribusi, dan pentingnya bidang-bidang pekerjaan terhadap/ bagi masyarakat dan tuntutan bagi pekerja dalam bidangbidang pekerjaan. (3) Mengidentifikasi bidangbidang pendidikan yang ada, baik yang segera maupun yang akan datang, sifat dan tujuanya, kesempatan menuju pendidikan tersebut dan secara tentatif memperkirakan apakah masing-masing itu mempunyai kemungkinan dipilih untuk suatu pekerjaan tertentu.(4) Mengidentifikasi keputusankeputusan yang harus dibuat pada waktu-waktu agar dapat mencapai tujuan-tujuan tersebut. (5) Memilih bidang pekerjaan (yang luas) dan mempelajarinya secara lebih mendalam. (6) Dapat memilih pendidikan dan latihan de ngan mengingat tujuan karir yang luas yang dipilihnya.

Faktor-faktor yang menghambat siswa dalam memanfaatkan layanan BK di sekolah kebanyakan terjadi karena kekeliruan pemahaman. Dalam hal ini, [3] telah mengidentifikasi 15 kekeliruan pemahaman siswa dalam melihat bimbingan dan konseling, baik dalam tataran konsep maupun praktiknya. Kekeliruan pemahaman ini tidak hanya terjadi di kalangan orang-orang yang berada di luar Bimbingan dan Konseling, tetapi juga banyak ditemukan di kalangan orang-orang yang terlibat langsung dengan bimbingan dan konseling. 
1. Bimbingan dan Konseling disamakan atau dipisahkan sama sekali dari pendidikan.

2. Menyamakan pekerjaan Bimbingan dan Konseling dengan pekerjaan dokter dan psikiater.

3. Bimbingan dan Konseling dibatasi pada hanya menangani masalah-masalah yang bersifat insidental.

4. Bimbingan dan Konseling dibatasi hanya untuk siswa tertentu saja.

5. Bimbingan dan Konseling melayani "orang sakit" dan/atau "kurang/tidak normal".

6. Pelayanan Bimbingan dan Konseling berpusat pada keluhan pertama (gejala) saja.

7. Bimbingan dan Konseling menangani masalah yang ringan.

8. Petugas Bimbingan dan Konseling di sekolah diperankan sebagai "polisi sekolah".

9. Bimbingan Konseling di anggap semata-mata sebagai proses pemberian nasihat

10. Bimbingan dan konseling bekerja sendiri atau harus bekerja sama dengan ahli atau petugas lain

11. Konselor harus aktif, sedangkan pihak lain harus pasif

12. Menganggap pekerjaan bimbingan dan konseling dapat dilakukan oleh siapa saja

13. Menyama-ratakan cara pemecahan masalah bagi semua klien

14. Memusatkan usaha Bimbingan dan Konseling hanya pada penggunaan instrumentasi

15. Menganggap hasil pekerjaan Bimbingan dan Konseling harus segera terlihat.

Faktor penghambat program layanan bk informasi karier menurut [4] dapat disimpulkan sebagai berikut:

1. Kurang adanya kerjasama kepala sekolah, guru bidang studi dan konselor.

2. Minimnya sarana dan prasarana sekolah dalam mendukung kinerja guru bk,

3. Kurang nya minat siswa dalam memanfaatkan layanan Bk

4. Frekuensi pertemuan yang jarang dilakukan karena tidak adanya pertemuan yang terjadwal dan berkala sehingga tukar menukar informasi hanya dilakukan seperlunya.

5. Waktu yang tersedia sangat terbatas.

6. Kurang mendapat dukungan sumber daya manusia atau tenaga ahli yang professional.

7. Kurang kerjasama dengan orang tua siswa.

Hambatan lain yang muncul menurut Pusat Layanan Konseling mahasiswa, Universitas Negeri Illinois (2005), terdapat beberapa faktor yang menyebabkan seorang siswa gagal dalam membuat pilihan keputusan karir. Takut akan kegagalan, takut sukses karena berpikiran orang lain mengharapkan kesempurnaan jika berhasil sekali, kurangnya kemampuan untuk menetapkan prioritas, tidak tahu tempat untuk mendapatkan informasi yang dibutuhkan untuk membantu memutuskan, berharap orang lain yang akan membuat keputusan, belum memiliki pengalaman dalam membuat keputusan karir, tidak mau mengorbankan kenyamanan untuk kepentingan kedepan, takut orang lain menolak keputusan yang telah di buat, selalu berpikir bahwa saya tidak dapat melakukannya jika orang lain pun tidak dapat melakukannya atau perasaan tidak percaya diri, dan percaya bahwa keputusan yang telah dibuat tidak akan ada yang peduli [5].

Upaya untuk mencapai sasaran hasil yang maksimal dalam kematangan karir, menurut [6] ada lima bidang yang perlu dikembangkan antara lain (1) Pengetahuan diri dan aspek lain, (2) Informasi studi, profesi dan karir.(3) Proses dalam menentukan keputusan karir. (4) Transisi menuju dunia kerja. (5) Perencanaan karir. Pendapat di atas menyatakan bahwa informasi karir mempunyai peran penting untuk peserta didik agar mencapai kematangan karir yang maksimal.

\section{Metode}

Penelitian ini menggunakan metode deskriptif yaitu, suatu metode penelitian yang memusatkan pemecahan masalah-masalah yang digunakan untuk membuat gambaran tentang suatu keadaan secara objektif pada situasi sekarang. Pengumpulan data pada penelitian ini menggunakan teknk wawancara, angket dan dokumentasi.

Penelitian memiliki keleluasaan untuk menentukan besarnya sampel apabila telah memenuhi persyaratan yang telah ditentukan maka dalam penelitian ini sampel yang digunakan sebesar $30 \%$, atau setelah dilakukan perhitungan 288 peserta didik sebagai populasi penelitian ini diperoleh sebanyak 85 peserta didik sebagai sampel. Adapun sampel penelitian disajikan pada tabel berikut :

TABEL I

SAMPEL PENELITIAN

\begin{tabular}{ccccc}
\hline No & Kelas & Populasi & Sampel & Keterangan \\
\hline 1 & VIII.1 & 36 & 10 & Sampel \\
2 & VIII.2 & 36 & 10 & yang \\
3 & VIII.3 & 36 & 10 & digunakan \\
4 & VIII.4 & 36 & 10 & sebesar \\
5 & VIII.5 & 36 & 10 & $30 \%$, \\
6 & VIII.6 & 36 & 10 & \\
7 & VIII.7 & 36 & 10 & \\
8 & VIII.8 & 36 & 10 & \\
\hline & Jumlah & 288 Orang & 80 Orang &
\end{tabular}

Cara pengambilan sampel dalam penelitian ini menggunakan random sampling adalah dengan cara membuat daftar semua anggota populasi dimana seluruh populasi diikuti untuk di pilih secara acak sebagai sampel dan disesuaikan dengan jumlah sampel sebesar 80 siswa (30\%).

\section{HASIL DAN PEMBAHASAN}

\section{A. HASIL}

Hasil analisis penyebaran kuesioner faktor-faktor yang menghambat siswa SMP Negeri 6 dalam memanfaatkan layanan informasi karir dipaparkan dalam tabel berikut ini: 
TABEL II

PENILAIAN TINGKAT FAKTOR-FAKTOR YANG MENGHAMBAT SISWA DALAM MEMANFAATKAN LAYANAN INFORMASI KARIER

\begin{tabular}{ccc}
\hline Item & Persentase Tingkat & Kategori \\
& Faktor-Faktor Yang & \\
Menghambat Siswa Dalam & \\
Memanfaatkan Layanan & Informasi Karier
\end{tabular}

\begin{tabular}{|c|c|c|}
\hline 1 & 41,25 & Kurang dominan \\
\hline 2 & 67,5 & Kurang dominan \\
\hline 3 & 85 & Dominan \\
\hline 4 & 75 & Cukup dominan \\
\hline 5 & 87,5 & Dominan \\
\hline 6 & 67,5 & Kurang dominan \\
\hline 7 & 41,25 & Kurang dominan \\
\hline 8 & 68,75 & Kurang dominan \\
\hline 9 & 87,5 & Dominan \\
\hline 10 & 75 & Cukup dominan \\
\hline 11 & 67,5 & Kurang dominan \\
\hline 12 & 62,5 & Kurang dominan \\
\hline 13 & 47,5 & Kurang dominan \\
\hline 14 & 37,5 & Kurang dominan \\
\hline 15 & 90 & Sangat dominan \\
\hline 16 & 75 & Cukup Dominan \\
\hline 17 & 85 & Dominan \\
\hline 18 & 65 & Kurang dominan \\
\hline 19 & 43,75 & Kurang dominan \\
\hline 20 & 60 & Kurang dominan \\
\hline 21 & 93,75 & Sangat dominan \\
\hline 22 & 88,75 & Dominan \\
\hline 23 & 63,75 & Kurang dominan \\
\hline 24 & 50 & Kurang dominan \\
\hline 25 & 62,5 & Kurang dominan \\
\hline 26 & 67,5 & Kurang dominan \\
\hline 27 & 90 & Sangat dominan \\
\hline 28 & 93,75 & Sangat dominan \\
\hline 29 & 85 & Dominan \\
\hline 30 & 88,75 & Dominan \\
\hline
\end{tabular}

Dari 30 item kuesioner faktor faktor yang menghambat siswa dalam memanfaatkan layanan informasi karir yang disebarkan menunjukkan hasil kategori Sangat dominan sebanyak 4 item, kategori dominan sebanyak 7 item, kategori cukup dominan sebanyak 3 item, dan kategori kurang dominan sebanyak 16 item.

\section{B. PEMBAHASAN}

Hasil penelitian dikelompokkan berdasarkan indikatorindikator variabel maka dapat direkapitulasikan sebagai berikut:
TABEL III

REKAPITULASI FAKTOR-FAKTOR YANG MENGHAMBAT SISWA DALAM MEMANFAATKAN LAYANAN INFORMASI KARIER BERDASARKAN INDIKATOR VARIABEL

\begin{tabular}{|c|c|c|c|}
\hline No. & Indikator Variabel & $(\%)$ & Kategori \\
\hline \multirow[t]{2}{*}{1.} & $\begin{array}{l}\text { Bimbingan dan Konseling } \\
\text { disamakan atau dipisahkan } \\
\text { sama sekali dari pendidikan. }\end{array}$ & \multirow[t]{2}{*}{54,37} & \multirow[t]{2}{*}{$\begin{array}{c}\text { Kurang } \\
\text { dominan }\end{array}$} \\
\hline & Menyamakan & & \\
\hline 2. & $\begin{array}{l}\text { Bimbingan dan Konseling } \\
\text { dengan pekerjaan dokter dan } \\
\text { psikiater. }\end{array}$ & 80 & Dominan \\
\hline 3. & $\begin{array}{l}\text { Bimbingan dan Konseling } \\
\text { dibatasi pada hanya } \\
\text { menangani masalah-masalah } \\
\text { yang bersifat insidental. }\end{array}$ & 77,5 & $\begin{array}{l}\text { Cukup } \\
\text { dominan }\end{array}$ \\
\hline 4. & $\begin{array}{l}\text { Bimbingan dan Konseling } \\
\text { dibatasi hanya untuk siswa } \\
\text { tertentu saja. }\end{array}$ & 55 & $\begin{array}{l}\text { Kurang } \\
\text { dominan }\end{array}$ \\
\hline 5. & $\begin{array}{lrr}\text { Bimbingan } & \text { dan } & \text { Konseling } \\
\text { melayani } & \text { "orang } & \text { sakit" } \\
\text { dan/atau } & & \text { "kurang/tidak } \\
\text { normal". } & & \end{array}$ & 81,25 & Dominan \\
\hline 6. & $\begin{array}{l}\text { Pelayanan Bimbingan dan } \\
\text { Konseling berpusat pada } \\
\text { keluhan pertama (gejala) saja. }\end{array}$ & 65 & $\begin{array}{l}\text { Kurang } \\
\text { dominan }\end{array}$ \\
\hline 7. & $\begin{array}{l}\text { Bimbingan dan Konseling } \\
\text { menangani masalah yang } \\
\text { ringan. }\end{array}$ & 42,5 & $\begin{array}{l}\text { Kurang } \\
\text { dominan }\end{array}$ \\
\hline 8. & $\begin{array}{lcr}\text { Petugas } & \text { Bimbingan } & \text { dan } \\
\text { Konseling } & \text { di } & \text { sekolah } \\
\text { diperankan } & \text { sebagai "polisi } \\
\text { sekolah". } & & \end{array}$ & 82,5 & Dominan \\
\hline 9. & $\begin{array}{l}\text { Bimbingan Konseling di } \\
\text { anggap semata-mata sebagai } \\
\text { proses pemberian nasihat }\end{array}$ & 75 & $\begin{array}{l}\text { Cukup } \\
\text { dominan }\end{array}$ \\
\hline 10. & $\begin{array}{l}\text { Bimbingan dan konseling } \\
\text { bekerja sendiri atau harus } \\
\text { bekerja sama dengan ahli atau } \\
\text { petugas lain }\end{array}$ & 51,87 & $\begin{array}{l}\text { Kurang } \\
\text { dominan }\end{array}$ \\
\hline 11. & $\begin{array}{l}\text { Konselor harus aktif, } \\
\text { sedangkan pihak lain harus } \\
\text { pasif }\end{array}$ & 91,25 & $\begin{array}{c}\text { Sangat } \\
\text { dominan }\end{array}$ \\
\hline 12. & $\begin{array}{l}\text { Menganggap } \\
\text { bimbingan dan kekerjaan } \\
\text { dapat dilakukan oleh siapa } \\
\text { saja }\end{array}$ & 56,87 & $\begin{array}{l}\text { Kurang } \\
\text { dominan }\end{array}$ \\
\hline 13. & $\begin{array}{l}\text { Menyama-ratakan } \\
\text { pemecahan masalah bagi } \\
\text { semua klien }\end{array}$ & 65 & $\begin{array}{l}\text { Kurang } \\
\text { dominan }\end{array}$ \\
\hline 14. & $\begin{array}{l}\text { Memusatkan usaha } \\
\text { Bimbingan dan Konseling } \\
\text { hanya pada penggunaan } \\
\text { instrumentasi }\end{array}$ & 91,87 & $\begin{array}{c}\text { Sangat } \\
\text { dominan }\end{array}$ \\
\hline 15. & $\begin{array}{l}\text { Menganggap hasil pekerjaan } \\
\text { Bimbingan dan Konseling } \\
\text { harus segera terlihat. }\end{array}$ & 86,87 & Dominan \\
\hline & Rata-rata & 70,45 & $\begin{array}{c}\text { Cukup } \\
\text { dominan }\end{array}$ \\
\hline Ber & $\begin{array}{l}\text { rkan tabel III tersebut di } \\
\text { faktor yang mengha }\end{array}$ & $\mathrm{ukkz}$ & $\begin{array}{l}\text { atawa rata- } \\
\text { dalam }\end{array}$ \\
\hline
\end{tabular}


Palangka Raya tahun ajaran 2016/2017 termasuk dalam kategori Cukup dominan dengan presentase 70,45\%.

Sedangkan bila dilihat dari masing-masing indikator variabel, urutan dari yang tertinggi sampai yang terendah presentasenya adalah sebagai berikut : 1) Memusatkan usaha Bimbingan dan Konseling hanya pada penggunaan instrumentasi sebesar 91,87\% dengan kategori Sangat dominan, 2) Konselor harus aktif, sedangkan pihak lain harus pasif sebesar 91,25\% dengan kategori Sangat dominan, 3) Menganggap hasil pekerjaan Bimbingan dan Konseling harus segera terlihat sebesar $86,87 \%$ dengan kategori dominan, 4) Petugas Bimbingan dan Konseling di sekolah diperankan sebagai "polisi sekolah" sebesar 82,5 \% dengan kategori dominan, 5) Bimbingan dan Konseling melayani "orang sakit" dan/atau "kurang/tidak normal" sebesar 81,25 \% dengan kategori dominan, 6) Menyamakan pekerjaan Bimbingan dan Konseling dengan pekerjaan dokter dan psikiater sebesar $80 \%$ dengan kategori dominan, 7) Bimbingan dan Konseling dibatasi pada hanya menangani masalah-masalah yang bersifat insidental sebesar 77,5 \% dengan kategori kurang dominan, 8) Bimbingan Konseling di anggap semata-mata sebagai proses pemberian nasihat sebesar $75 \%$ dengan kategori cukup dominan, 9) Menyama-ratakan cara pemecahan masalah bagi semua klien sebesar $65 \%$ dengan kategori kurang dominan, 10) Pelayanan Bimbingan dan Konseling berpusat pada keluhan pertama (gejala) saja sebesar $65 \%$ dengan kategori kurang dominan, 11) Menganggap pekerjaan bimbingan dan konseling dapat dilakukan oleh siapa saja sebesar 56,87\% dengan kategori kurang dominan, 12) Bimbingan dan Konseling dibatasi hanya untuk siswa tertentu saja sebesar 55 \% dengan kategori kurang dominan, 13) Bimbingan dan Konseling disamakan atau dipisahkan sama sekali dari pendidikan sebesar 54,37 \% dengan kategori kurang dominan, 14) Bimbingan dan konseling bekerja sendiri atau harus bekerja sama dengan ahli atau petugas lain sebesar 51,87\% dengan kategori kurang dominan, 15) Bimbingan dan Konseling menangani masalah yang ringan sebesar $42,5 \%$ dengan kategori kurang dominan.

Hal ini sejalan dengan hasil wawancara dengan 10 (sepuluh) yang menyatakan bahwa konselor harus aktif, sedangkan siswa pasif, bimbingan dan konseling fungsi hanya untuk melakukan tes, menyamakan pekerjaan bimbingan dan konseling dengan pekerjaan dokter dan psikiater, bimbingan dan konseling melayani "orang sakit" dan/atau "kurang/tidak normal", menganggap hasil pekerjaan bimbingan dan konseling harus segera terlihat.

Layanan informasi merupakan salah satu dari beberapa kegiatan dalam rangka pelaksanaan program bimbingan di sekolah untuk membantu siswa mengenal lingkungannya yang di manfaatkan baik saat ini maunpun di masa yang akan datang" [7]. Layanan informasi bertujuan untuk memberikan siswa dengan berbagai pengetahuan dan pemahaman tentang berbagai hal yang berguna untuk mengenal diri.

Faktor-faktor yang menghambat siswa dalam memanfaatkan layanan BK disekolah kebanyakan terjadi karena kekeliruan pemahaman. Dalam hal ini, [3] telah mengidentifikasi 15 kekeliruan pemahaman siswa dalam melihat bimbingan dan konseling, baik dalam tataran konsep maupun praktiknya. Kekeliruan pemahaman ini tidak hanya terjadi di kalangan orang-orang yang berada di luar Bimbingan dan Konseling, tetapi juga banyak ditemukan di kalangan orang-orang yang terlibat langsung dengan bimbingan dan konseling.

1. Bimbingan dan Konseling disamakan atau dipisahkan sama sekali dari pendidikan.

2. Menyamakan pekerjaan Bimbingan dan Konseling dengan pekerjaan dokter dan psikiater.

3. Bimbingan dan Konseling dibatasi pada hanya menangani masalah-masalah yang bersifat insidental.

4. Bimbingan dan Konseling dibatasi hanya untuk siswa tertentu saja.

5. Bimbingan dan Konseling melayani "orang sakit" dan/atau "kurang/tidak normal".

6. Pelayanan Bimbingan dan Konseling berpusat pada keluhan pertama (gejala) saja.

7. Bimbingan dan Konseling menangani masalah yang ringan.

8. Petugas Bimbingan dan Konseling di sekolah diperankan sebagai "polisi sekolah".

9. Bimbingan Konseling di anggap semata-mata sebagai proses pemberian nasihat

10. Bimbingan dan konseling bekerja sendiri atau harus bekerja sama dengan ahli atau petugas lain

11. Konselor harus aktif, sedangkan pihak lain harus pasif

12. Menganggap pekerjaan bimbingan dan konseling dapat dilakukan oleh siapa saja

13. Menyama-ratakan cara pemecahan masalah bagi semua klien

14. Memusatkan usaha Bimbingan dan Konseling hanya pada penggunaan instrumentasi

15. Menganggap hasil pekerjaan Bimbingan dan Konseling harus segera terlihat.

Minimnya pemanfaatan layanan informasi karir di SMP Negeri 6 Palangka raya tahun ajaran 2016/2017 di sebabkan karena kekeliruan pemahaman siswa dalam memahami layanan bimbingan konseling di sekolah. Berdasarkan hasil penelitian tersebut maka dapat diketahui bahwa secara umum faktor-faktor penghambat siswa kelas VIII dalam memanfaatkan layanan informasi karier di SMP Negeri 6 Palangka raya tahun ajaran 2016/2017 berada pada tingkat kategori Cukup dominan dengan persentase rata-rata 70,45\%.

\section{KESIMPULAN}

Pemahaman siswa terhadap faktor-faktor yang menghambat siswa dalam memanfaatkan layanan informasi karier di SMP Negeri 6 Palangka Raya Tahun Ajaran 2016/2017 meliputi (1) Bimbingan dan Konseling disamakan atau dipisahkan sama sekali dari pendidikan, (2) Menyamakan pekerjaan Bimbingan dan Konseling dengan pekerjaan dokter dan psikiater, (3) Bimbingan dan Konseling dibatasi pada hanya menangani masalah-masalah yang bersifat insidental, (4) Bimbingan dan Konseling dibatasi hanya untuk siswa tertentu saja, (5) Bimbingan dan Konseling melayani "orang sakit" dan/atau "kurang/tidak normal", (6) Pelayanan Bimbingan dan Konseling berpusat pada keluhan pertama (gejala) saja, (7) Bimbingan dan Konseling menangani 
masalah yang ringan, (8) Petugas Bimbingan dan Konseling di sekolah diperankan sebagai "polisi sekolah", (9) Bimbingan Konseling di anggap semata-mata sebagai proses pemberian nasihat, (10) Bimbingan dan konseling bekerja sendiri atau harus bekerja sama dengan ahli atau petugas lain, (11) Konselor harus aktif, sedangkan pihak lain harus pasif, (12) Menganggap pekerjaan bimbingan dan konseling dapat dilakukan oleh siapa saja, (13) Menyama-ratakan cara pemecahan masalah bagi semua klien, (14) Memusatkan usaha Bimbingan dan Konseling hanya pada penggunaan instrumentasi, (15) Menganggap hasil pekerjaan Bimbingan dan Konseling harus segera terlihat.

Berdasarkan urutan tingkat pemahaman siswa terhadap faktor-faktor yang mempengaruhi siswa dalam memanfaatkan layanan informasi karier di SMP Negeri 6 Palangka Raya Tahun Ajaran 2016/2017 dari yang tertinggi sampai yang terendah adalah sebagai berikut : 1) Memusatkan usaha Bimbingan dan Konseling hanya pada penggunaan instrumentasi sebesar 91,87\% dengan kategori Sangat dominan, 2) Konselor harus aktif, sedangkan pihak lain harus pasif sebesar 91,25\% dengan kategori Sangat dominan, 3) Menganggap hasil pekerjaan Bimbingan dan Konseling harus segera terlihat sebesar $86,87 \%$ dengan kategori dominan, 4) Petugas Bimbingan dan Konseling di sekolah diperankan sebagai "polisi sekolah" sebesar 82,5 \% dengan kategori dominan, 5) Bimbingan dan Konseling melayani "orang sakit" dan/atau "kurang/tidak normal" sebesar 81,25\% dengan kategori dominan, 6) Menyamakan pekerjaan Bimbingan dan Konseling dengan pekerjaan dokter dan psikiater sebesar $80 \%$ dengan kategori dominan, 7) Bimbingan dan Konseling dibatasi pada hanya menangani masalah-masalah yang bersifat insidental sebesar 77,5 \% dengan kategori kurang dominan, 8) Bimbingan Konseling di anggap semata-mata sebagai proses pemberian nasihat sebesar $75 \%$ dengan kategori cukup dominan, 9) Menyama-ratakan cara pemecahan masalah bagi semua klien sebesar $65 \%$ dengan kategori kurang dominan, 10) Pelayanan Bimbingan dan Konseling berpusat pada keluhan pertama (gejala) saja sebesar $65 \%$ dengan kategori kurang dominan, 11) Menganggap pekerjaan bimbingan dan konseling dapat dilakukan oleh siapa saja sebesar 56,87\% dengan kategori kurang dominan, 12) Bimbingan dan Konseling dibatasi hanya untuk siswa tertentu saja sebesar 55 $\%$ dengan kategori kurang dominan, 13) Bimbingan dan Konseling disamakan atau dipisahkan sama sekali dari pendidikan sebesar 54,37 \% dengan kategori kurang dominan, 14) Bimbingan dan konseling bekerja sendiri atau harus bekerja sama dengan ahli atau petugas lain sebesar 51,87\% dengan kategori kurang dominan, 15) Bimbingan dan Konseling menangani masalah yang ringan sebesar 42,5\% dengan kategori kurang dominan.

Secara keseluruhan bahwa tingkat pemahaman siswa tentang faktor-faktor yang menghambat siswa dalam memanfaatkan layanan informasi karier di SMP Negeri 6 Palangka Raya Tahun Ajaran 2016/2017 dalam kategori kategori Cukup dominan dengan persentase rata-rata 70,45\%.

\section{DAFTAR PUSTAKA}

[1] Sukardi, D.K. (2004). Bimbingan Konseling Di Sekolah. Jakarta : Rineka Cipta

[2] Slameto. (2010). Belajar dan Faktor-Faktor yang Mempengaruhinya. Jakarta : PT. Rineka Cipta.

[3] Prayitno. (2003). Wawasan dan Landasan BK (Buku II). Depdiknas: Jakarta

[4] Winkel, W.S., \& Hastuti, S. (2010). Bimbingan Dan Konseling di Institusi Pendidikan. Yogyakarta: Media Abadi.

[5] Student Counseling Services. Diakses pada Desember 22, 2016, dari https://counseling.illinoisstate.edu/career/

[6] Alvarez, G.M. (2008). Career Maturity: a Priority for Secondary. Education. Journal of Researching Educational Psychology, 6(3), 749772 .

[7] Sukardi, D.K. (1987). Bimbingan Karir Di Sekolah-sekolah. Jakarta: Ghalia Indonesia. 